\title{
MENGATASI STRESS SAAT PANDEMIK DENGAN MEMBUAT BUKU MEWARNAI (Di IEEEL Institute, Tangerang)
}

\author{
Aprilia Kartini $^{1)}$ \\ ${ }^{1)}$ Desain Komunikasi Visual/Teknologi dan Desain, Universitas Bunda Mulia \\ Diterima 19 Maret 2021 / Disetujui 26 Maret 2021
}

\begin{abstract}
During the Corona Virus Disease-2019 (Covid-19) pandemic, which has been going on for almost 1 (one) year, many people feel confused, anxious, afraid, and some are also frustrated. This pandemic has an impact on various sectors, such as economy, education, tourism, social and many more. Feelings of fear of contracting and facing death alone and other worries that everyone thinks about so that the level of stress is getting higher. There has been a change in lifestyle that is usually spent with friends now mostly alone at home or boarding house. Those who already have a family have a heavier burden, especially when it comes to dealing with work when working from home or WFH. Coupled with taking care of children's school and household activities. Stress is a person's emotional response caused by external problems or when facing various life problems. To some extent, stress is needed to be prepared to face the threat of problems. This kind of stress is called eustress or normal stress. However, if the stress is prolonged and causes suffering to turn into distress and can cause mental health problems, this should be avoided. One way to deal with stress during a pandemic can be done by making pictures. As stated by Herawati and Iriaji, they argue that drawing is a tool to express thoughts. During a pandemic when people are worried about leaving the house, coloring books are an alternative to relieve stress. But the obstacle is that people are afraid to leave the house to buy books and also during the economic situation in the family that must be regulated because many do not receive full salaries, so making their own coloring books is an alternative.
\end{abstract}

Keywords: Pandemic, Covid-19, Drawing, Books, Coloring

\begin{abstract}
ABSTRAK
Pada masa pandemi Corona Virus Disease-2019 (Covid-19) saat ini yang sudah berlangsung hampir 1 (satu) tahun membuat banyak orang merasa bingung, cemas, takut, dan juga ada yang frustasi. Pandemik ini berdampak ke berbagai sektor seperti ekonomi, pendidikan, pariwisata, sosial dan banyak lagi. Perasaan takut tertular dan menghadapi kematian seorang diri dan kecemasan lainnya yang dipikirkan oleh setiap orang sehingga tingkat stress semakin tinggi. Terjadi perubahan gaya hidup yang biasanya dihabiskan bersama temanteman sekarang lebih banyak sendiri di rumah atau tempat kost. Yang sudah memiliki keluarga beban terasa lebih berat terutama dalam hal menghadapi pekerjaan saat working from home atau WFH. Ditambah dengan mengurus kegiatan sekolah anak dan rumah tangga. Stres adalah respons emosional seseorang yang disebabkan masalah eksternal atau ketika menghadapi berbagai persoalan kehidupan. Dalam kadar tertentu, stress dibutuhkan untuk bisa siaga menghadapi ancaman permasalahan. Stress seperti ini disebut eustress atau stress yang normal. Namun, kalau stresnya berkepanjangan dan menimbulkan penderitaan akan berubah menjadi distress dan dapat menimbulkan gangguan kesehatan mental, ini yang harus dihindari. Menghadapi stress saat pandemik salah satunya bisa dilakukan dengan cara membuat gambar. Seperti yang diungkapkan oleh Herawati dan Iriaji berpendapat bahwa menggambar adalah alat untuk mengungkapkan pikiran. Pada masa pandemik dimana orang khawatir untuk keluar rumah maka buku mewarnai menjadi salah satu alternatif untuk menghilangkan stress tersebut. Tetapi kendala yang ada adalah orang takut keluar rumah untuk membeli buku dan juga pada saat ekonomi dalam keluarga yang harus diatur karena banyak yang tidak penuh menerima gaji atau penghasilan maka membuat buku mewarnai sendiri menjadi salah satu alternatif.
\end{abstract}

Kata Kunci: Pandemic, Covid-19, Menggambar, Buku, Mewarnai

*Korespondensi Penulis:

E-mail: astreit@bundamulia.ac.id 


\section{PENDAHULUAN}

\section{Latar Belakang}

Tahun ini seluruh dunia mengalami kejadian luar biasa yaitu pandemik dari virus Covid 19. Ruang gerak menjadi terbatas juga pertemuan dengan keluarga dan kolega. Kegiatan di dalam rumah yang dilakukan terus menerus menyebabkan banyak orang mengalami kenaikan tingkat stress. Ada yang mempunyai waktu luang yang sangat banyak waktu dirumah atau saat work from home (WFH), atau ada yang bebannya menjadi bertambah berat terutama keluarga yang memiliki anak usia sekolah dan juga sebagai orangtua yang harus bekerja di rumah saat pandemik.

Merangkum akun Instagram Inspektorat Jenderal Kementerian Pendidikan dan Kebudayaan ( Kemendikbud), Selasa (29/9/2020), berikut ini 6 tips hindari stress di masa pandemi bagi siswa maupun masyarakat: 1. Terapkan gaya hidup sehat Jaga asupan makanan dan istirahat yang cukup. Olahraga untuk menjaga kondisi tubuh dan sering-sering mencuci tangan. 2 . Lakukan aktivitas atau hobi di waktu luang Coba lakukan kegiatan yang menyenangkan yang dapat mengalihkan pikiran kita. Lakukan hobi yang bisa dilakukan di rumah.

3. Komunikasi dengan orang terdekat Ceritakan kecemasan yang dialami pada keluarga atau sahabat yang dapat dipercaya. Jika tidak bisa bertemu langsung, maka bisa melalui telepon atau video call. 4 . Tenangkan diri Cobalah untuk tetap tenang dan berpikiran positif. Berdoa atau meditasi dapat membantu proses menenangkan diri. 5. Baca info dari sumber terpercaya Carilah informasi yang akurat dan dari sumber terpercaya. Sehingga kita bisa memperkirakan resiko dan merencanakan tindakan pencegahan. 6 . Kurangi intensitas melihat media online Banyaknya berita yang berkembang di media massa media sosial atau televisi bisa membuat kita semakin cemas dan takut.
Dikutip dari halodoc, Menurut Girija Kaimal dari College of Nursing and Health Professions di Drexel University di Philadelphia, PA, dan rekannya baru-baru ini menerbitkan temuan mereka di The Arts in Psychotherapy. Dalam penelitian tersebut, ada 26 orang dewasa sehat berusia antara 18 dan 70 tahun, delapan di antaranya adalah seniman. Untuk penelitian ini, semua peserta diminta untuk terlibat dalam tiga tugas pembuatan seni yang berbeda (mewarnai, mencoret-coret, atau menggambar bebas), dan masing-masing berlangsung selama 3 menit dengan waktu istirahat di antaranya. Selama setiap tugas, aktivitas otak peserta dipantau menggunakan spektroskopi inframerah-dekat fungsional, yang merupakan teknik pencitraan yang mengukur aliran darah di daerah otak tertentu.

Dosen adalah pendidik profesional yang bekerja di satuan pendidikan tinggi tertentu. Dosen kerap disebut sebagai Ilmuwan karena kapasitas ilmu yang ia miliki. Tugas utama seorang dosen adalah mengembangkan dan menyebarluaskan ilmu pengetahuan, teknologi, juga seni melalui Tri Dharma Pendidikan Tinggi. Selain melaksanakan perkuliahan, dosen bersama dengan mahasiswa dan perguruan tinggi, diharapkan dapat terus berkontribusi melakukan penelitian dan memberikan pelayanan pada masyarakat dan ikut terlibat dalam kegiatan yang menunjang pelaksanaan tugas umum pemerintah dan pembangunan. Dalam memenuhi Tri Dharma Pendidikan Tinggi, yaitu pegabdian kepada masyarakat (PKM) dirasa perlu adanya kegiatan berbagi keilmuan melalui webinar kepada masyarakat dengan mengangkat sebuah topik yang memiliki potensi dalam peningkatan keilmuan Desain Komunikasi Visual (DKV) dan perkembangan industri kreatif terutama di masa pandemik. Adapun materi yang dibawakan sesuai dengan mata kuliah dalam kurikulum Prodi Desain Komunikasi Visual Universitas Bunda Mulia yaitu Gambar, teori warna dan Ilustrasi 
Melalui webinar ini diharapkan mampu diberikan pengetahuan dan informasi, berdasarkan keilmuan Desain Komunikasi Visual terutama dalam pembuatan gambar yang sederhana, pembuatan ilustrasi dan juga psikologi warna. Dengan adanya kegiatan ini maka para civitas academika diharapkan dapat memahami manfaat, tujuan, dalam pembuatan buku mewarnai sesuai dengan kerangka akademik.

\section{a. Identifikasi Masalah}

Seperti yang sudah dituliskan dalam latar belakang dimana pada masa pandemik Covid19 yang sudah berlangsung selama hampir setahun menyebabkan banyak orang yang merasa cemas bahkan sampai pada taraf stress dalam menjalani kehidupan pada masa pandemik ini.

Psikolog Ina M. Surya Dewi mengatakan, seni termasuk menggambar, bisa menjadi alat berekspresi dan mengeluarkan perasaan seseorang. Ina merupakan sahabat Maria dan yang menyarankannya menggambar.Terapi seni dianggap bisa menjadi salah satu cara mengurangi stress dan ini juga digunakan oleh salah satu pasien COVID-19 Maria Darmaningsih. Wanita ini merupakan pasien kedua ketika virus ini pertama kali menyebar di Indonesia. Maka untuk mengatasi masalah stress pada saat pandemik ini menggambar dan mewarnai menjadi alternatif murah untuk menghilangkan stress.

Eksistensi perguruan tinggi ditentukan oleh kemampuannya memberi kontribusi pada masyarakat. Pengabdian masyarakat memiliki esensi yang sangat penting bagi aspek tata guna laksana dari pengembangan ilmu pengetahuan. Atas dasar nilai-nilai normatif tersebut di atas Program Studi Desain

Komunikasi Visual Universitas Bunda Mulia Jakarta melakukan pelatihan pembuatan buku mewarnai untuk para peserta yang bergabung dalam IEEEL Tangerang.

\section{b. Tujuan dan Manfaat Kegiatan}

Adapun maksud dan tujuan dari diselenggarakan kegiatan PKM ini adalah untuk:

1. Academika IEEEL Institute Tangerang ini dapat memperoleh pemahaman dan pengetahuan bagaimana mengatasi stress dimasa pandemik dengan membuat buku mewarnai.

2. Dengan membuat buku ilustrasi untuk mewarnai diharapkan dapat mengurangi stress dengan cara menggambar dan belajar memahami warna sebagai bagian dari terapi saat stress.

3. Dalam keilmuan DKV mahasiswa juga diajarkan bagaimana warna mempengaruhi manusia sehingga mempelajari warna menjadi bagian yang penting ketika belajar desain.

\section{METODE PENELITIAN}

Kegiatan pengabdian kepada masyarakat ini diberikan dalam rangka mengatasi stress yang banyak terjadi pada masa pandemik Covid-19. Dengan menggunakan metode penelitian Tindakan kolaboratif dan partisipatori (participatory action research/ PAR) yaitu kegiatan penelitian yang dilakukan dengan melibatkan masyarakat agar merasa ikut serta memiliki program kegiatan tersebut serta berniat ikut aktif memecahkan masalah berbasis masyarakat (Suharsimi Arikunto, 2006: 95). Masyarakat yang dimaksud dalam penelitian ini adalah para peserta academika dari IEEEL Institute, Tangerang.

Dalam teori PAR terdapat siklus yang dijadikan tolak ukur keberhasilan proses penelitian berbasis pemberdayaan masyarakat. Adapun siklus tersebut dikenal dengan istilah KUPAR (to Know, to 
Understand, to Plan, to Action dan to Reflection). To Know (untuk mengetahui) merupakan proses awal dalam pemberdayaan dengan mempertimbangkan pandangan subyektif peneliti terhadap kehidupan masyarakat yang diteliti, serta membangun kesepakatan sehingga peneliti diterima oleh masyarakat tersebut. To Understand (untuk memahami) dimaknai sebagai suatu proses dimana peneliti dan masyarakat yang diberdayakan mampu mengidentifikasi permasalahan yang ada dalam kehidupan mereka, kemudian dikolerasikan dengan asetaset yang dimiliki masyarakat, sehingga dapat mewujudkan komitmen masyarakat dalam menyelesaikan permasalahan yang ada dalam kehidupan mereka. To Plan (untuk merencanakan) sebagai proses merencanakan aksi-aksi strategis dalam menyelesaikan persoalan yang muncul dalam masyarakat. Perencanaan ini mempertimbangkan keseimbangan antara human resources dan natural resources serta alur stakeholder yang menghimpun masyarakat tersebut. Tahap perencanaan ini harus dimaksimalkan dengan kesertaan penuh masyarakat atas penyelesaian masalahnya sendiri. Sehingga pemberdayaan tidak hanya diartikan sebagai perubahan sosial saja, namun juga media pendidikan masyarakat. To Action (melancarkan aksi) merupakan implementasi produk pemikiran masyarakat untuk membangun, mengelola, merubah, menajamkan aset-aset yang dimiliki masyarakat sehingga dapat difungsikan secara optimal dan proposional. To Reflection (refleksi) merupakan tahapan dimana peneliti dan masyarakat mengevaluasi dan memonitoring aksi pemberdayaan yang telah dilakukan sehingga pemberdayaan menjadi terarah dan terukur.

\section{HASIL DAN PEMBAHASAN}

Sebelum merencanakan penelitian ini dilakukan terlebih dahulu observasi terhadap masalah yang banyak dihadapi pada masa pandemik ini. Ruang gerak menjadi terbatas juga pertemuan dengan keluarga dan kolega.
Kegiatan didalam rumah yang dilakukan terus menerus menyebabkan banyak orang mengalami kenaikan tingkat stress. Ada yang mempunyai waktu luang yang sangat banyak waktu dirumah atau saat WFH, atau ada yang bebannya menjadi bertambah berat terutama keluarga yang memiliki anak usia sekolah dan juga sebagai orangtua yang harus bekerja di rumah saat pandemik.

Pengertian menggambar adalah aktivitas kreatif untuk membentuk imaji/gambar yang menyampaikan gagasan, ide, serta simbol sebagai salah satu bentuk ekspresi menggunakan berbagai teknik guratan dan alat gambar yang beranekaragam. Sejalan dengan pernyataan di atas, Herawati dan Iriaji (Herawati dan Iriaji, 1997) berpendapat bahwa menggambar adalah alat untuk mengungkapkan pikiran.

Konsep Seni Sebagai Hiburan yang Menyenangkan Konsep ini berpendapat bahwa hasil seni harus dapat menghibur atau menyenangkan pengamat. Hal tersebut dikemukakan oleh Soehardjo (2012: 106) bahwa: "Seni berpotensi untuk dimanfaatkan sebagai objek pelipur lara bagi khalayak.

Secara fisik, menggambar hanyalah mengguratkan alat gambar untuk mencurahkan imaji yang ada di pikiran kita, baik itu meniru alam ataupun tidak (imajinasi murni). Namun sejatinya gambar adalah bahasa universal yang dikenal jauh sebelum manusia mengenal tulisan.

Kemudian bekerjasama dengan P3M Universitas Bunda Mulia peneliti melakukan PKM ini dengan memilih kelompok masyarakat yang banyak berdampak pandemik yaitu masyarakat yang bekerja terutama bekerja penuh di kantor dan juga para akademika yang biasa mengajar secara langsung dan juga beberapa wanita yang bekerja juga menjadi ibu rumah tangga selesai bekerja. 
Kegiatan ini dilakukan melalui WAG secara online karena pada masa pandemik tidak memungkinkan untuk membuat acara dengan mengumpulkan orang banyak dengan jumlah peserta WAG sebanyak 214 orang Kegiatan ini diawali dengan pembukaan dan pemberian materi dalam bentuk PPT dan juga video tutorial yang juga dipresentasikan secara online melalui WAG.

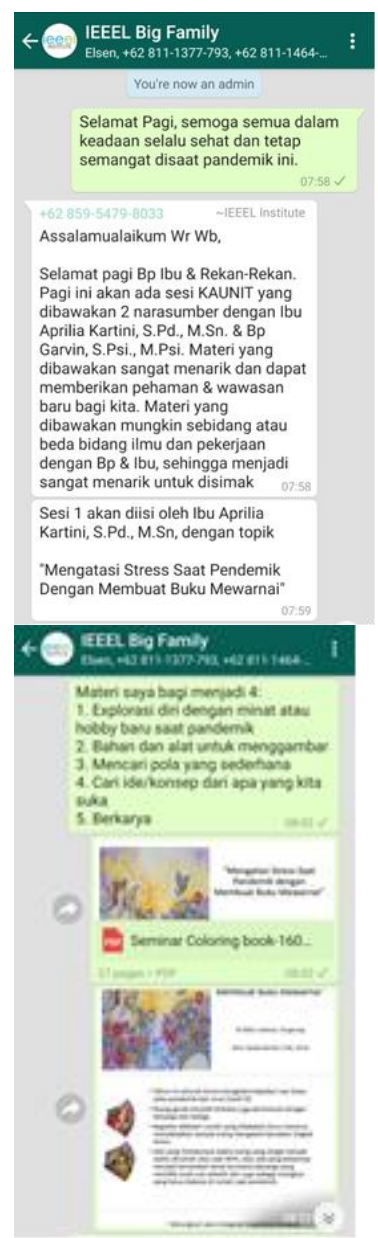

Gambar 1. Opening dan penjelasan materi (Sumber: Penulis, 2021)

\section{$\leftarrow \quad$ IEEEL Big Family \\ Created by +62 859-5479-8033, 06/11... \\ 214 participants \\ Elsen Mhs UBM \\ Group Admin \\ +62 818-0837-1000 \\ Group Admin \\ +62 859-5479-8033 \\ Group Admin \\ WA dikelola oleh Tim Sale... IEEEL Institute}

\section{Gambar 2. Jumlah Peserta PKM}

(Sumber: Penulis, 2021)

Adapun pemberian contoh cara membuat buku selain dengan menggunakan video tutorial juga dengan menggunakan PPT yang sudah dibagikan sebelumnya. Peserta selain membaca dari PPT yang sudah diberikan, peneliti juga mempresentasikan di WAG mengenai pembahasan materi PKM tersebut.

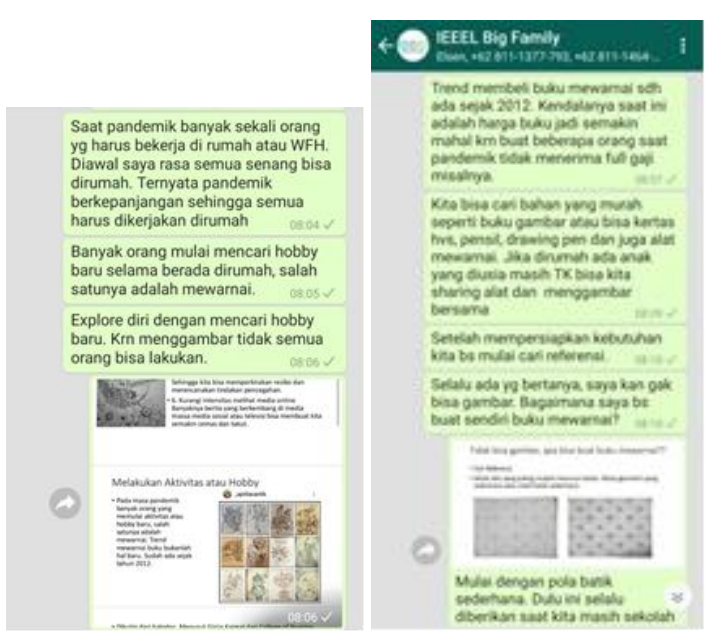

Gambar 3. Materi -1 PKM

(Sumber: Penulis, 2021) 


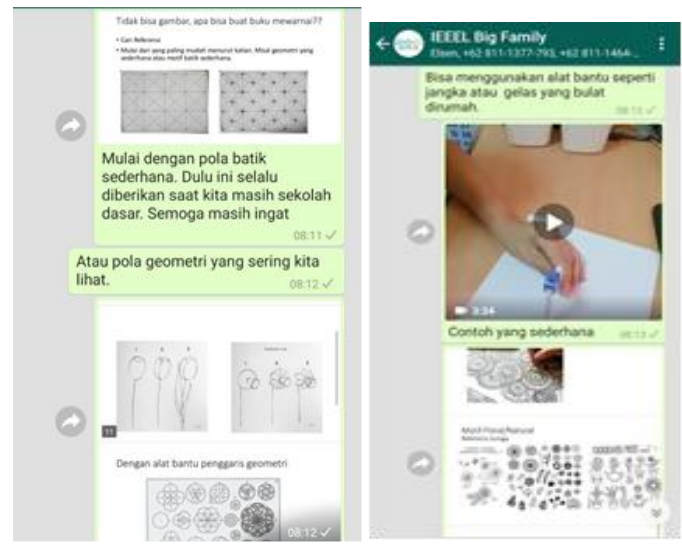

Gambar 4. Materi -2 PKM

(Sumber: Penulis, 2021)

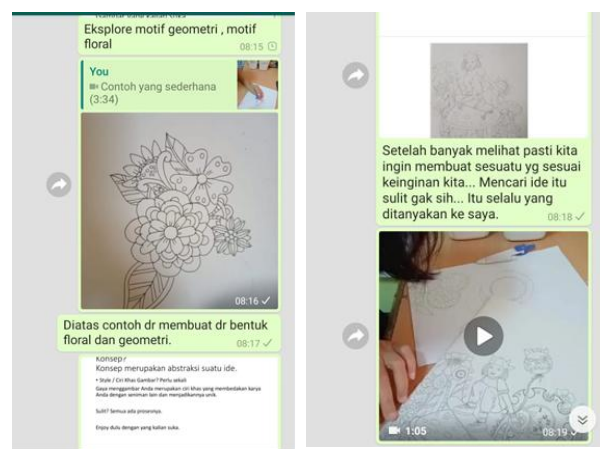

Gambar 5. Materi -3 PKM

(Sumber: Penulis, 2021)

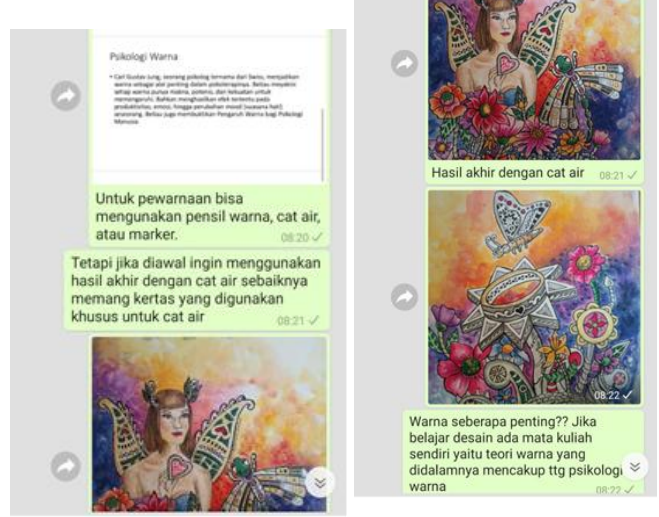

Gambar 6. Materi -4 PKM

(Sumber: Penulis, 2021)

Setelah materi disampaikan peserta dapat bertanya mengenai materi yang sudah dijelaskan sebelumnya.

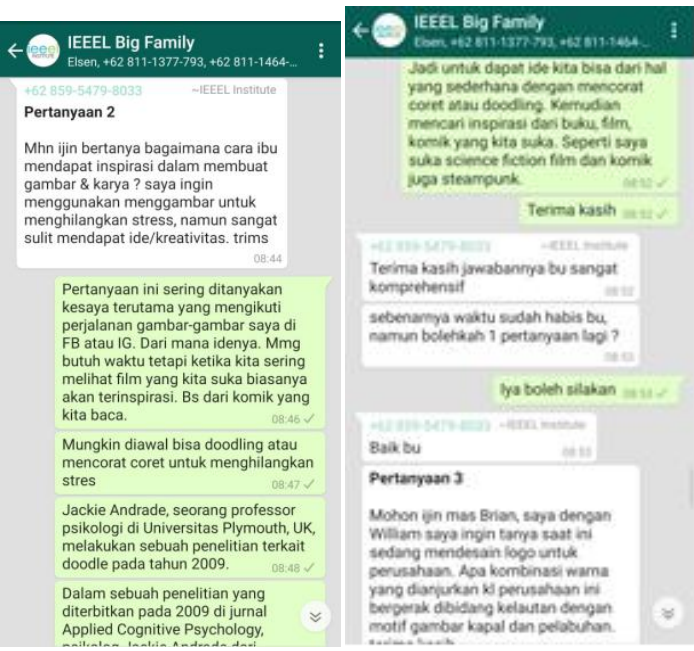

\section{Gambar 7. Pertanyaan PKM}

(Sumber: Penulis, 2021)

Pertanyaan yang diberikan oleh peserta adalah bagaimana membangun ide atau kreativitas. Untuk orang yang sudah biasa dengan membuat gambar atau ilustrasi maka tidak akan mengalami kesulitan. tetapi yang mungkin akan sulit untuk sebagian orang yang tidak pernah menggambar. Disini peneliti memberikan saran bahwa diawal kita dapat melihat referensi yang sudah ada untuk menciptakan sebuah karya ilustrasi.

Peneliti memberikan materi yang disesuaikan dengan peserta PKM dimana tidak semua peserta memiliki kemampuan menggambar yang baik. Peneliti memberikan Langkah-langkah menggambar yang mudah untuk para peserta PKM.

Adapun contoh gambar yang digunakan dalam pelatihan ini adalah berupa bentuk geometri yang sederhana. Bentuk-bentuk tersebut kemudian diolah menjadi sebuah gambar dekoratif yang menarik. Jika peserta sudah menguasai bentuk yang sederhana maka akan dilanjutkan menggambar yang lebih rumit dengan konsep yang disesuaikan dengan kemampuan masing-masing peserta PKM.

Langkah-langkah yang dilakukan dalam pembuatan buku mewarnai sebagai berikut: 
1. Langkah awal adalah mempersiapkan alat dan bahan seperti kertas gambar, pensil, pena hitam, penggaris, alat bantu lain berupa penggaris yang memiliki bentuk geometri.

2. Mencari referensi gambar.

Referensi sangat diperlukan terutama yang baru mulai belajar menggambar.

Tidak bisa gambar, apa bisa buat buku mewarnai??

- Cari Referensi

- Mulai dari yang paling mudah menurut kalian. Misal geometri yang sederhana atau motif batik sederhana.
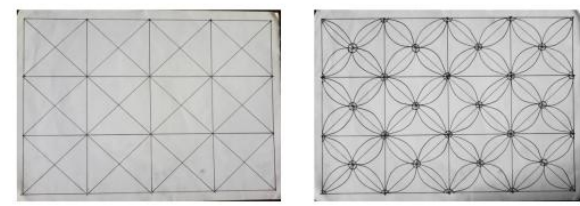

Motif Floral/Natural

Referensi bunga

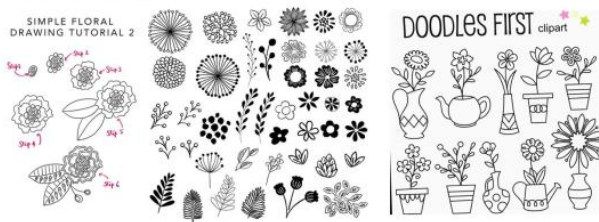

\section{Gambar 8. Referensi gambar}

(Sumber: Internet, 2021)

3. Mulai berlatih menggambar dengan membuat bentuk yang sederhana.

Mulai dengan bentuk yang sederhana

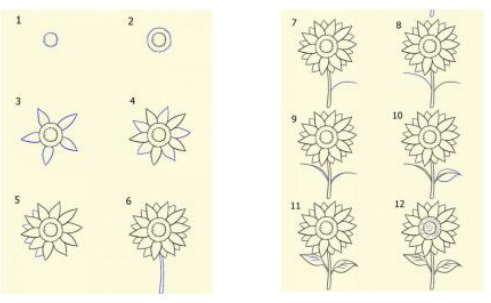

Gambar 9. Contoh pembuatan gambar yang sederhana

(Sumber: Penulis, 2021)

4. Membuat gambar yang lebih rumit dengan bantuan penggaris geometri.
Dengan alat bantu penggaris geometri

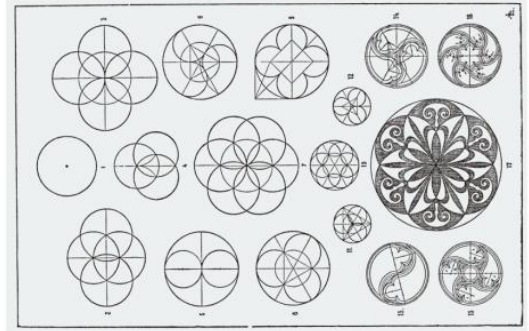

Gambar 10. Contoh gambar dengan menggunakan alat bantu penggaris geometri

(Sumber: Internet, 2021)

5. Stylel Gaya menggambar Anda merupakan ciri khas yang membedakan karya Anda dengan seniman lain dan menjadikannya unik. Jika sudah mulai terbiasa dengan menggambar bentuk yang rumit maka perlu membuat sebuah konsep gambar ilustrasi yang disukai.

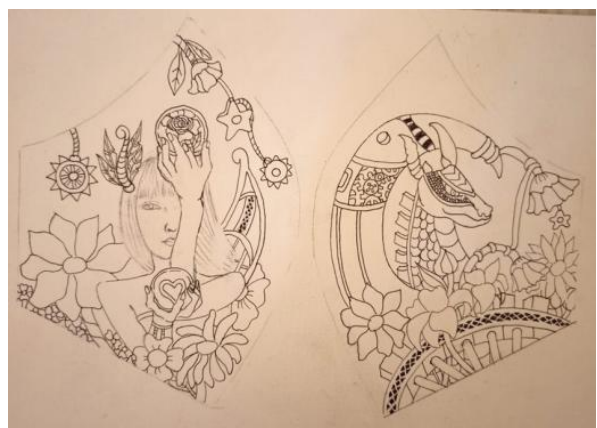

Gambar 11. Gambar ilustrasi peneliti

(Sumber: Penulis, 2021)

6. Penerapan warna sebagai bagian dari terapi seni, buku mewarnai untuk dewasa bisa digunakan untuk mengatasi gangguan mental dan psikologi. Penerapan warna menjadi tahap terakhir ketika gambar ilustrasi sudah kita buat. 


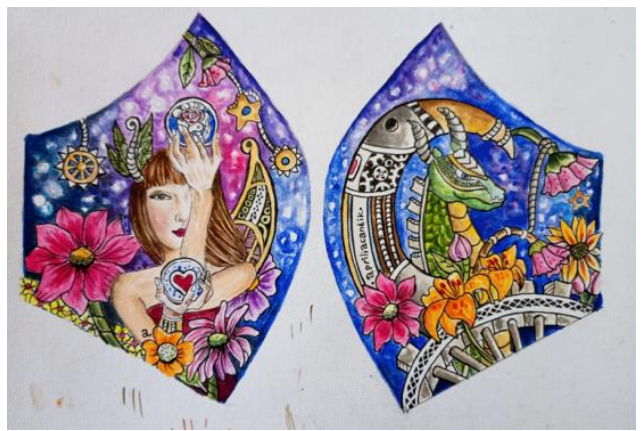

Gambar 12. Ilustrasi yang sudah diwarnai (Sumber: Penulis, 2021)

Hasil dari gambar ilustrasi yang dibuat para peserta PKM bisa dijadikan masker, dimana pada saat pandemic ini masker menjadi bagian yang tidak bisa dipisahkan jika kita berada diluar rumah.

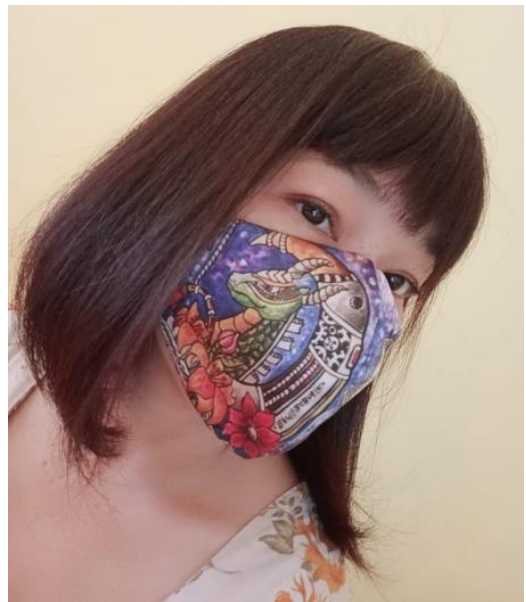

Gambar 13. Aplikasi gambar untuk masker kain

(Sumber: Penulis, 2021)

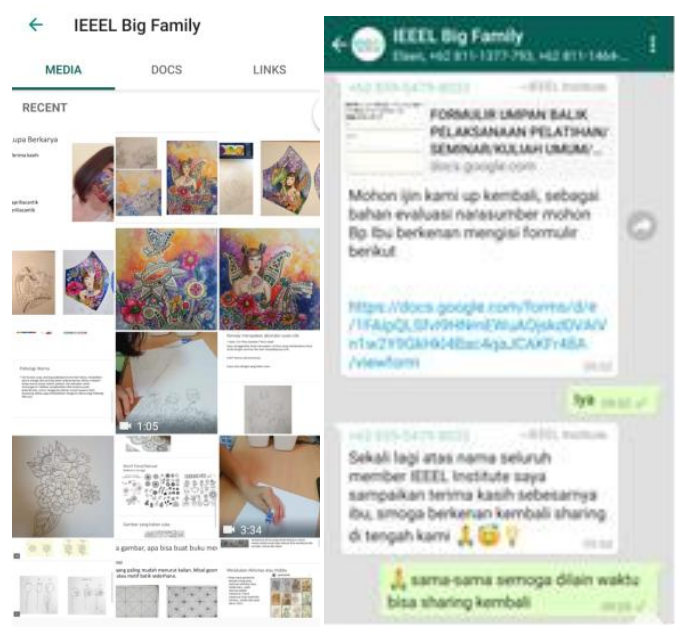

\section{Gambar 14. Hasil Gambar dan umpan balik PKM}

(Sumber: Penulis, 2021)

\section{SIMPULAN}

Hasil materi yang diberikan tentang bagaimana membuat buku mewarnai

1. Para peserta dari IEEEL Institute yang mengikuti kegiatan ini sangat antusias dengan materi yang saat ini berguna saat mengatasi pandemik.

2. Materi berupa membuat buku mewarnai sendiri sangat bermanfaat karena menjadi alternatif hobby baru untuk masyarakat dalam mengatasi pandemik.

3. Kemampuan peserta dalam menggambar tidak seluruhnya bisa terutama dalam membuat bentuk yang rumit.

4. Kesulitan peserta dalam mengembangkan ide/kreativitas sehingga diperlukan pembelajaran yang lebih dalam untuk membuat ilustrasi.

\section{DAFTAR PUSTAKA}

Agus Afandi, dkk. (2013). Modul Participatory Action research (PAR). Surabaya: LPPM.

Arikunto, Suharsimi. (2006). Prosedur Penelitian Suatu Pendekatan Praktik. Jakarta: Rineka Cipta.

Herawati, I. S. dan Iriaji. (1997). Pendidikan Seni Rupa. Jakarta: Depdikbud.

Soehardjo, A. J. (2012). Pendidikan Seni: Dari Konsep Sampai Program. Malang: UNM.

https://edukasi.kompas.com/read/2020/09/2 9/153624671/6-tips-hindari-stressaat-pandemi-darikemendikbud?page $=$ all

https://www.halodoc.com/artikel/inimanfaat-doodling-untuk-kesehatanmental

https://voi.id/berita/6020/terapi-seni-yangbisa-menambah-imunitas-tubuh 